\title{
Erratum to: The effects of paroxetine given repeatedly on the 5-HT receptor subpopulations in the rat brain
}

\author{
J. Maj ${ }^{1}$ M. Bijak ${ }^{1}$ - M. Dziedzicka-Wasylewska ${ }^{1}$.

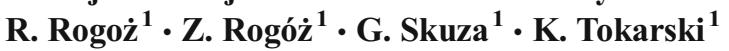

Published online: 27 October 2015

(C) Springer-Verlag Berlin Heidelberg 2015

Erratum to: Psychopharmacology

DOI 10.1007/BF02805977

The original version of the above article contained a mistake in one of the author names. T. Tokarski should be K. Tokarski.

The online version of the original article can be found at http://dx.doi.org/ 10.1007/BF02805977.

\footnotetext{
K. Tokarski

ktok@if-pan.krakow.pl

Institute of Pharmacology, Polish Academy of Sciences, 12 Smetna Street, 31343 Kraków, Poland
} 